\title{
LOST AT THE EQUAL PROTECTION CARNIVAL: NELSON LUND'S CARNIVAL OF MIRRORS
}

\author{
Laurence H. Tribe*
}

Talk about losing sight of the forest for the trees! What I trust interests readers is what to make of the equal protection twist in Bush v. Gore, not an exchange of volleys between scholars. That exchange having descended from the trivial to the absurd, ${ }^{1}$ I want to return to the substance of the equal protection issue that has perplexed Bush v. Gore's observers from day one. It is worth noting initially Professor Lund's inability to dispute the per curiam opinion's conspicuous failure to identify any individual voters, or groups of voters, who were treated unequally by the Florida Supreme Court's ballot counting scheme. Nor could he dispute my argument that the deviations present in the Florida court's recount order were characteristic of the degrees and kinds of deviations that a reasonable reading of Reynolds $v$. Sims and its progeny permitted. ${ }^{2}$ Rather than engaging these arguments, Professor Lund has replied with a barrage of technical, literalist defenses of both his Carnival of Mirrors and the Court's opinion. I have space in this response to address only two of Lund's replies.

First is Professor Lund's assertion that the remedy in Bush v. Gore did not "foreclose the Florida court from ordering a new recount." Lund is, of course, technically correct that the per cu-

* Tyler Professor of Constitutional Law, Harvard Law School.

1. Exemplifying Professor Lund's latest assault on my scholarship is his decision to pounce on my mistake of writing that Lund had described something I had written about Bush v. Gore as "unexceptional," when in fact he had actually used the word "unexceptionable." See Nelson Lund, Carnival of Mirrors: Laurence Tribe's "Unbearable Wrongness", 19 Const. Comm. 609 \& note 3 (2003) ("Carnival"). Professor Lund's Carnival had responded to Laurence $H$. Tribe, The Unbearable Wrongness of Bush v. Gore, 19 Const. Comm. 571 (2003) ("Unbearable Wrongness"). Why anyone would make so much of an obviously unintentional error whose correction wouldn't have weakened my point in the slightest is a mystery to me.

2. See Tribe, Unbearable Wrongness at 582-84, 585-87 (cited in note 1).

3. Lund, Carnival at 615 (cited in note 1). 
riam opinion didn't order the Florida Supreme Court in so many words to toss in the towel. ${ }^{4}$ But anyone who could seriously depict the opinion as a mere suggestion that the Florida court consider it quits would fail to see the humor in the cartoon captioned: "'Shut up!', he explained." Even assuming the leeway the Court theoretically left open was real, the window it had failed to slam shut was hardly the sort of opening through which anyone would dare to crawl. To describe the opinion's language 5 as only encouraging an end to the dispute is a gross understatement. The Court's "time's-up!" decree readily explains why nearly every observer, including Vice President Gore, understood the decision to end the Election 2000 dispute. $^{6}$

More fundamentally, the alleged December 12 "deadline"-cited by the per curiam opinion two hours before that midnight as the justification for finding that a uniform recount could not proceed-was not, as Lund suggests, the result of the Florida Supreme Court's "own ... questionable interpretation of the state statutes." To the contrary, it was the U.S. Supreme Court that cobbled the deadline together from a variety of opinions that, viewed individually or collectively, could not support the proposition that Florida law - as written or as authoritatively construed-imposed a hard-and-fast deadline on the recount process. Justice Shaw, who dissented from the Florida Supreme Court decision that ruled in favor of Vice President Gore, explained that "December 12 was [never] a 'drop-dead' date under Florida law," but "was simply a permissive 'safe-harbor' date to which the states could aspire. It certainly was not a mandatory contest deadline under the plain language of the Florida Election Code (i.e., it is not mentioned there) or this Court's prior rulings." ${ }^{8}$ And the prior opinions on which the Court explicitly relied merely discussed "the Florida Secretary of State's authority to reject late returns arising from a pre-certification protest

4. The Court did close with the traditional phrase remanding the dispute to the Florida court for "proceedings not inconsistent with this opinion." Bush v. Gore, 531 U.S. $98,111(2000)$.

5. Tribe, Unbearable Wrongness at 589 n.78 (cited in note 1).

6. See, e.g., Gore, 773 So. $2 d$ at 529 (Shaw, J., concurring) (arguing that the "tenor" of Bush v. Gore precluded the Florida Supreme Court from crafting "a remedy under these circumstances that would have met the due process, equal protection, and other concerns of the United States Supreme Court"); Lund, Carnival at 616 n.32 (cited in note 1) (citing Ron Klain's belief that the Court's decision "seemed to have the word 'stop' written on it in really big letters").

7. Lund, Carnival at 614 (cited in note 1).

8. Gore v. Harris, 773 So. 2d 524, 528-29 (Fla. Dec. 22, 2000) (Shaw, J., concurring). 
action, not ... a court's obligation to stop a recount in a postcertification contest action. To mix these two actions is to confuse apples and oranges." 9 The U.S. Supreme Court was the only court to find "a legislative wish to take advantage of the "safe harbor" $" 10$ in the relevant context of that contest phase.

Finally, even if the Florida court had explicitly read the December 12 date as a binding deadline, deferring to that "interpretation" contradicted the Court's equal protection holding. The Court did not deny the Florida court's conclusion on December 8 that hundreds of ballots had been lawfully cast under Florida law - evinced by partial and completed recounts ${ }^{11}$ - yet were not tallied in Katherine Harris's certified count. ${ }^{12}$ Throwing out these ballots to satisfy a non-mandatory safe harbor provision systematically and arbitrarily "diluted" to zero the weight of hundreds of votes for no reason other than the inadequacy of the vote counting machines in their home counties. And Professor Lund neither explains nor justifies the Court's willingness to tolerate the fact that, in the count certified by Harris, some counties had completed manual recounts including overvotes while some had not, or the fact that some counties never completed the statutorily required automatic recount at all. ${ }^{13}$

Professor Lund's only response is a procedural cheap-shot: "[t]he Court was not obliged to somehow anticipate and accept Professor Tribe's unlitigated, post hoc claims." ${ }^{14}$ Even if this description were accurate, the Bush v. Gore majority most cer-

9. Id. at $529 \mathrm{n} .12$ (internal citations omitted). Justice Shaw's point is illustrated by Palm Beach County Canvassing Bd. v. Harris, 772 So. 2d 1220, 1237 (Fla. Nov. 21, 2000) (arguing that the Secretary of State may ignore late returns in an initial certification if doing so would preclude "Florida voters from participating fully in the federal electoral process" but saying nothing of a final deadline in an election contest); and Palm Beach County Canvassing Bd. v. Harris, 772 So. 2d 1273, 1289 (Fla. Dec. 11, 2000) (discussing 3 U.S.C. $\S 5$ only in relation to the Secretary of State's "discretion to ignore amended returns" in a protest to an election certification).

10. Bush v. Palm Beach County Canvassing Bd., 531 U.S. 70, 78 (2000); see also John C. Yoo, In Defense of the Court's Legitimacy, 68 U. Chi. L. Rev. 775, 790 (2001) ("Indeed, the per curiam's sudden introduction of the December 12 cutoff date for a remedy - based on the assumption that the Florida legislature intended to adopt the safe harbor date for the selection of presidential electors provided for by 3 USC \$ 5-makes almost no sense at all unless read in light of the concurrence's structural analysis.").

11. See Gore v. Harris, 772 So. 2d 1243, 1248 (Fla. 2000).

12. See Gore v. Harris, 772 So. $2 \mathrm{~d} 1243,1258-62$ (Fla. 2000). I have discussed numerous other inequalities in the underlying count elsewhere. See Tribe, Unbearable Wrongness at 584 (cited in note 1); Laurence $H$. Tribe, eroG .v hsuB and its Disguises: Freeing Bush v. Gore from its Hall of Mirrors, 115 Harv. L. Rev. 170, 258-63 (2001).

13. See Tribe, Unbearable Wrongness at 580-81 (cited in note 1); see also Tribe, 115 Harv. L. Rev. at 261 (cited in note 12).

14. Lund, Carnival at 615 n.31 (cited in note 1). 
tainly was obliged to respond to the arguments made by the dissenting Justices who argued that reading a December 12 deadline into the Florida election code-thereby ending any realistic chance of an amended recount-would violate the very equal protection principle through which the Court invalidated the recount. ${ }^{15}$ But Lund's cheap shot isn't just cheap; it's wrong. My brief on behalf of Vice President Gore plainly did argue that the equal protection theory of Petitioner Bush would apply equally to the disparities present in the underlying count and in the counts certified in numerous other states. ${ }^{16}$ And even if it hadn't, Professor Lund should have perhaps thought twice before mocking my failure to say explicitly that the underlying count certified by Katherine Harris was plagued with unconstitutional inequalities more serious and numerous than the count ordered by the Florida Supreme Court. After all, my client, whom I was bound by law to represent faithfully, believed that neither the underlying count nor the Florida court's ordered recount violated the Fourteenth Amendment. For him, the dispute was solely about Florida election law. It seems odd indeed to fault the Vice President, who believed he had won a majority of Florida's popular votes in accord with Florida's laws, for not wanting to make a federal case out of it.

15. See Bush v. Gore, 531 U.S. 98, 126-27 (Stevens, J., dissenting) ("Florida law holds that all ballots that reveal the intent of the voter constitute valid votes. Recognizing these principles, the majority nonetheless orders the termination of the contest proceeding before all such votes have been tabulated. Under their own reasoning, the appropriate course of action would be to remand to allow more specific procedures for implementing the legislature's uniform general standard to be established."); id. at 147 (Breyer, J., dissenting) ("By halting the manual recount, and thus ensuring that the uncounted legal votes will not be counted under any standard, this Court crafts a remedy... [that] harms the very fairness interests the Court is attempting to protect.... [V]oters already arrive at the polls with an unequal chance that their votes will be counted. I do not see how the fact that this results from counties' selection of different voting machines rather than a court order makes the outcome any more fair.").

16. See Brief of Respondent Albert Gore, Jr., at 35-36, Bush v. Gore, 531 U.S. 98 (2000) ("Of course, so long as the count is conducted by humans, it undeniably will be possible to allege some degree of inconsistency in the treatment of individual ballots... . That will be true in every one of the many jurisdictions that provide for manual recounts; it is true whenever States provide for variation in the methods of voting from county to county (e.g., optical scanners as opposed to less reliable punch card ballots), which is now the case in every State; and it was true everywhere prior to the introduction of mechanical voting machines, when all ballots were counted by hand. Petitioners' theory would mean that all of these practices violate the Fourteenth Amendment. Moreover, if petitioners mean to say that all votes must be tabulated under a fixed and mechanical standard (e.g., the 'two-corner chad rule'), their approach would render unconstitutional the laws of States that hinge the meaning of the ballot on the intent of the voter - and also would mean that the Constitution requires the disenfranchisement of many voters whose intent is clearly discernible. This argument, in our view, is wholly insubstantial."). 
The second of Professor Lund's arguments that space permits me to address is his accusation that $I$ have invented out of thin air a political process doctrine with no relationship to the opinions in Bush v. Gore. ${ }^{17}$ To be sure, my articulation of that doctrine takes a fresh look at, and revises, the traditional formulation of Baker v. Carr. ${ }^{18}$ Again, Professor Lund is technically correct-neither Justice Breyer nor Justice Souter uttered the magic words: "this case is nonjusticiable under the political question doctrine." Yet both made numerous arguments that employed the essential building blocks of the doctrine I have articulated. ${ }^{19}$ And the "conflat[ion of] the... doctrine of nonjusticiable political questions" with arguments "about the proper exercise of judicial discretion" ${ }^{20}$ is hardly an invention to which I can lay claim. To the contrary, this conflation is pervasive in constitutional law. Nonjusticiability is often articulated through arguments about ripeness and reminders of the passive virtues, a point aptly illustrated by the Court's unanimous decision in Growe v. Emison, about which Professor Lund is silent. ${ }^{21}$

Doctrinal labels are notoriously misleading; at times, their false advertising can lure even the most sophisticated of observers into a hall of mirrors that distorts more than it reveals. But in the case of Bush v. Gore, it takes relatively little sophisticationjust a resistance to sophistry-to recognize how far one must twist equal protection law to make it fit the decision's mold.

17. See Lund, Carnival at 616-18 (cited in note 1).

18. See Tribe, Unbearable Wrongness at 593-601 (cited in note 1).

19. Id. at 604-05.

20. Lund, Carnival at 618 (cited in note 1).

21. See Tribe, Unbearable Wrongness at 598-99, 605-06 (cited in note 1). 